\title{
Differences in Copper Isotope Fractionation Between Mussels (Regulators) and Oysters (Hyperaccumulators): Insights from a Ten-Year Biomonitoring Study
}

\author{
Ferreira Araujo Daniel 1, ${ }^{*}$, Ponzevera Emmanuel ${ }^{1}$, Briant Nicolas ${ }^{1}$, Knoery Joel ${ }^{1}$, Bruzac Sandrine ${ }^{1}$, \\ Sireau Teddy ${ }^{1}$, Grouhel-Pellouin Anne ${ }^{2}$, Brach-Papa Christophe ${ }^{3}$
}

${ }^{1}$ Laboratoire de Biogéochimie des Contaminants Métalliques, Ifremer, Centre Atlantique, Nantes Cedex 3 F44311, France

2 Réseau d'Observation de la Contamination Chimique du littoral-ROCCH, Ifremer, Centre Atlantique, Nantes Cedex 3 F44311, France

${ }^{3}$ Laboratoire Environnement Ressources Provence-Azur-Corse, Ifremer, Centre Méditerranée, Zone

Portuaire de Brégaillon, La Seyne-sur-Mer Cedex CS20 330 83507, France

* Corresponding author : Daniel Ferreira Araujo, email address : daniel.ferreira.araújo@ifremer.fr

\begin{abstract}
:
Copper $(\mathrm{Cu})$ isotope compositions in bivalve mollusks used in marine-monitoring networks is a promising tool to monitor anthropogenic $\mathrm{Cu}$ contamination in coastal and marine ecosystems. To test this new biomonitoring tool, we investigated $\mathrm{Cu}$ isotope variations of two bivalves - the oyster Crassostrea gigas and the mussel Mytilus edulis-over 10 years (2009-2018) in a French coastal site contaminated by diffuse $\mathrm{Cu}$ anthropogenic sources. Each species displayed temporal concentration profiles consistent with their bioaccumulation mechanisms, that is, the Cu-regulating mussels with almost constant $\mathrm{Cu}$ concentrations and the Cu-hyperaccumulating oysters with variable concentrations that track $\mathrm{Cu}$ bioavailability trends at the sampling site. The temporal isotope profiles were analogous for both bivalve species, and an overall shift toward positive $\delta 65 \mathrm{Cu}$ values with the increase of $\mathrm{Cu}$ bioavailabilities was associated with anthropogenic $\mathrm{Cu}$ inputs. Interestingly, mussels showed wider amplitudes in the isotope variations than oysters, suggesting that each species incorporates Cu isotopes in their tissues at different rates, depending on their bioaccumulation mechanisms and physiological features. This study is the first to demonstrate the potential of $\mathrm{Cu}$ isotopes in bivalves to infer $\mathrm{Cu}$ bioavailability changes related to anthropogenic inputs of this metal into the marine environment.
\end{abstract}




\section{Graphical abstract}

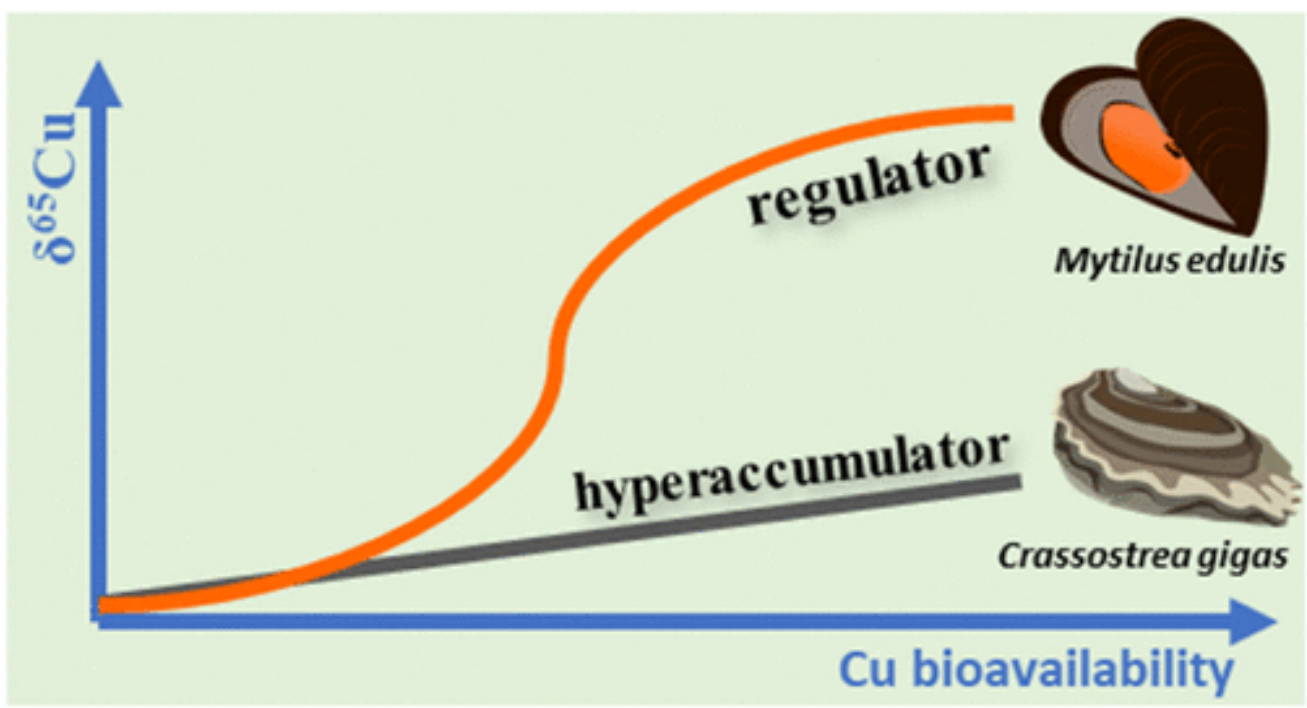




\section{Introduction}

Copper isotopes are fractionated in nature by a multitude of biogeochemical processes, such as redox reactions, ${ }^{1,2}$ complexation, ${ }^{3}$ adsorption ${ }^{4,5}$ and transport across membranes. ${ }^{6,7}$ The variability of $\mathrm{Cu}$ isotope abundances produced by these processes can provide useful information about its sources, ${ }^{8-10}$ transport, ${ }^{11-14}$ and transfers across interfaces of geochemical compartments. ${ }^{15-17}$

The perspectives to extract environmental information using $\mathrm{Cu}$ isotope compositions of biomonitors, like bivalve mollusks, are of great interest. As filter feeders, these organisms incorporate (or "bioaccumulate") trace metals available to them from the dissolved and particulate phases (mainly phytoplankton) of aquatic systems. Since their tissues are thought to provide a time-integrated picture of metal bioavailability, ${ }^{18-20}$ time series of bivalve tissues are useful to monitor trends on trace metal bioavailability of coastal and marine environments. ${ }^{19,21,22}$ Due to their advantageous features as globally abundant, sessile and tolerant to environmental stresses, bivalves have been used worldwide in biomonitoring programs such as so-called "Mussel Watch Programs" implemented in many locations including the USA, Europe and Asia. ${ }^{21-23}$ Pioneering surveys on $\mathrm{Zn}$ and $\mathrm{Cd}$ isotope compositions of coastal bivalves on Canadian, American, Brazilian and French coasts have reported a wide geographical isotope variability, ${ }^{24-27}$ while controlled laboratory experiments showed that oysters record the $\mathrm{Zn}$ isotope signatures of $\mathrm{Zn}$ sources. ${ }^{28}$ To our knowledge, $\mathrm{Cu}$ isotope systematics in bivalve organisms have not yet been reported in the literature. Interestingly, $\mathrm{Cu}$, like $\mathrm{Zn}$, has a dual role as both a nutrient and a contaminant in bivalves. It is co-factor in many proteins, including hemocyanin, the main oxygen protein carrier in the blood of these organisms. ${ }^{19}$ However, the exposure of bivalves to high bioavailable levels of $\mathrm{Cu}$ in contaminated sites can induce deleterious effects to their endocrine systems ${ }^{29}$, and abnormalities during larval life stages of bivalves. ${ }^{30}$ 
In the present study, we investigated $\mathrm{Cu}$ isotope variations over ten years in two bivalve species - hyperaccumulator oysters (Crassotrea gigas, Thunberg, 1793), and regulator mussels (Mytilus edulis, Linnaeus, 1758) - harvested in a coastal environment under the influence of diffuse anthropogenic $\mathrm{Cu}$ inputs. The trace metal body burden on bivalves depends of metal pollution levels, ${ }^{20,31}$ biological factors (body size, age, spawning period, homeostasis $)^{32-36}$ and, environmental parameters that control metal speciation and bioavailability $\left(\mathrm{Eh},{ }^{37} \mathrm{pH},{ }^{38}\right.$ temperature, ${ }^{39}$ salinity,${ }^{40,41}$ primary production, ${ }^{42}$ etc. $)$. The intricate combination of these variables limits the use of elemental data to distinguish anthropogenic inputs from natural ones where contaminant metal levels are close to background levels. Thus, in this work, we investigate if $\mathrm{Cu}$ isotope compositions in bivalve mollusks soft tissues can vary with $\mathrm{Cu}$ bioavailability changes related to anthropogenic inputs of this metal.

\section{Material and methods}

\section{Bivalve mollusk sampling and sample preparation}

The bivalve mollusks' tissue samples were acquired from the sample collection of France's monitoring framework ROCCH (Réseau d'Observation de la Contamination Chimique), which is operated by the French Research Institute for Exploitation of the Sea (Ifremer). Each sample consists of a pool of the soft tissues of either > fifty individual mussels, or > ten oysters. In this study, we selected oysters (Crassostrea gigas) and mussels (Mytilus edulis) from the "Pointe Er Fosse" sampling station (47 $37^{\circ} 31.788^{\prime \prime} \mathrm{N} ; 2^{\circ} 38^{\prime} 46.8168^{\prime \prime} \mathrm{W}$ ), located in the tidal flat of the Pénerf river mouth that connects to the Vilaine Bay (Biscay Bay, French Atlantic coast). The chosen samples were collected annually in February during the winter season, between 2009 and 2018. Samples from the same season decreases the possible influence on isotope compositions of seasonally-varying parameters such as time in the organism's spawning cycle, time on the floristic composition of the bivalve's planktonic food, sea temperature and composition (salinity, oxygen content, $\mathrm{pH}$ ), insolation, $\mathrm{pH}$, Eh, light, diet, etc. 
The Pénerf river watershed is mainly rural upstream, accounting with several agro-food industries, and more urban in downstream with two tourist resort towns, the Tour du Parc and Damgan. ${ }^{43}$ An important local mariculture activity has developed there since the end of the $\mathrm{XIX}^{\text {th }}$ century. At the Pointe Er Fosse station, ROCCH biomonitoring is carried out since 1990 on mussels and since 2009 on oysters. Available $\mathrm{Cu}$ and $\mathrm{Zn}$ elemental data from ROCCH program for mussels encompassing the last four decades shows a slight decrease in the bioaccumulation of these metals after 2003 (Supporting information, Fig. S1).

Bivalve sampling and preparation of the $\mathrm{ROCCH}$ program were performed as described by Claisse et al. ${ }^{44}$ After collection from their natural oyster or mussel bed, the sampled bivalves were cleaned of epibiota and kept for $24 \mathrm{hrs}$. in approximately $20 \mathrm{~L}$ of filtered seawater taken from the collection site. This depuration step eliminates feces and pseudo-feces from the digestive tracts of the animals, and hence eliminates the compositional influence of the animal's last meal. Next, individual bivalves were selected on the basis of shell length criterion to normalized body size or age parameters. Bivalves were then shucked, dripped dry in a Buchner funnel and frozen. Subsequently, frozen samples were thawed, blended and homogenized, and freeze-dried. They were stored in acid-cleaned glass containers in the dark, at ambient conditions.

\section{Sample digestion and elemental analysis}

About $200 \mathrm{mg}$ aliquots of dry bivalve tissue samples were digested with nitric acid solution using a microwave system (Ethos Up, ThemoFisher). After sample digestion, aliquots from the final extract solution were split for subsequent elemental and isotope analyses. Procedural blanks and reference materials were processed together with each batch of 10 samples, and followed the entire procedure (digestion, elemental analysis, ion chromatography and isotope determination). Certified reference materials included oyster, mussel and fish tissues (SRM 1566b, NIST®; ERM-CE278k, ERM®; DORM-4, NRC-CNRC®). All reagents, labware acid- 
cleaning and dilution solutions for elemental and isotope analyses were prepared with 18.2 M $\Omega . c m \mathrm{H}_{2} \mathrm{O}$ (Nanop System ${ }^{\circledR}$ ), and ultra-pure acids (PlasmaPure Plus grade, SCP science®). Elemental concentrations of $\mathrm{Cu}$ and $\mathrm{Zn}$ were determined by inductively coupled plasma mass spectrometry (ICP-MS, iCAP Qc, Thermo Fisher Scientific).

\section{Copper isotope analysis}

Prior to isotope analysis, aliquots of the final extract of digested samples were processed through ion-exchange chromatography columns using a modified protocol of Maréchal et al. ${ }^{45}$ to isolate the $\mathrm{Cu}$ analyte from matrix elements. Chromatographic recovery yields (around 100 $\pm 10 \%$ ) and the procedural blanks ( $<1 \%$ of total $\mathrm{Cu}$ mass aliquots) were verified by ICP-MS.

Copper isotopes were measured at the Pôle Spectrométrie Océan (Ifremer, Brest, France) using MC-ICP-MS (Neptune, Thermo Scientific) with a Stable Introduction System (SIS: cyclonic spray chamber and PFA nebulizer at $50 \mu \mathrm{L} \mathrm{min}^{-1}$, ESI). Samples were prepared in $2 \%(\mathrm{v} / \mathrm{v}) \mathrm{HNO}_{3}$, and introduced at concentrations kept between 100 and $300 \mathrm{ng} \mathrm{g}^{-1}$. Raw isotope ratios were corrected for instrumental mass discrimination using sample/standard bracketing combined with an external normalization technique using $\mathrm{Zn}$-doping. The final $\mathrm{Cu}$ isotope compositions are expressed as $\delta^{65} \mathrm{Cu}$ in relation to the isotope certified reference material (iCRM) NIST SRM-976 (Eq. 1).

$$
\delta^{65} C u_{S R M-976}(\% 0)=\left(\frac{R\left(\frac{{ }^{65} \mathrm{Cu}}{{ }^{63} \mathrm{Cu}}\right)_{\text {sample }}}{R\left(\frac{{ }^{65} \mathrm{Cu}}{{ }^{63} \mathrm{Cu}}\right)_{\text {SRM-976 }}}-1\right) \times 1000 \text { (Eq. 1) }
$$

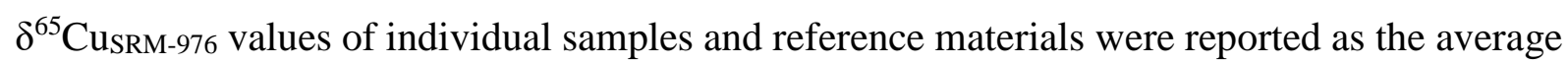
and the two-standard deviation (2s) of two measurements performed during a single analytical session. For analytical accuracy and reproducibility control, we assessed $\delta$-zero measurements for different iCRM SRM-976 aliquots proceed on the chromatography column $\left(\delta^{65} \mathrm{Cu}_{\mathrm{SRM}-976}=\right.$ 
$+0.01 \pm 0.07 \%, \mathrm{n}=4,2 \mathrm{~s})$ and the $\delta^{65} \mathrm{Cu}$ values obtained for reference materials (RMs) of biological matrices (Table 1). The $\delta$-average external reproducibility of biological RMs prepared in distinct replicates following the full protocol, including sample digestion, ionexchange chromatography and replicated isotope analyses in the different analytical section was about $\pm 0.05 \%$. Our analysis of the RM fish protein DORM-4 $(+0.55 \pm 0.02 \%$, Table 1$)$ agreed well with the two published values for this material $\left(+0.52 \pm 0.08^{46}\right.$ and +0.48 $\pm 0.06 \%{ }^{47}$ ). The rapid advance of the stable metal isotope field has not been accompanied by the supplying of reference materials (RMs) with organic matrixes over the last two decades. ${ }^{46-}$

${ }^{48}$ As we are unaware of published $\mathrm{Cu}$ isotope values for reference materials of bivalve tissues, we provide new $\mathrm{Cu}$ isotope data for three commercially available $\mathrm{RMs}$ to allow future interlaboratory comparisons and quality assurances (Table 1).

\section{Results and discussion}

Elemental and isotope range variations in bivalve mollusks in a ten-year biomonitoring

The complete bivalve datasets (Table S1 and Table S2) for the 2009 to 2018 period are included in the SI. Oysters present higher $\mathrm{Cu}$ concentrations than mussels by a factor of approximately 22. In these hyperaccumulator organisms, Cu concentrations vary from 69 to $244 \mu \mathrm{g} \mathrm{g}^{-1}$, with an average of $132 \pm 54 \mu \mathrm{g} \mathrm{g}^{-1}$ (RSD 41\%). In turn, the mussel M. edulis shows homogenous $\mathrm{Cu}$ concentrations varying between 5.3 and $7.1 \mu \mathrm{g} \mathrm{g}^{-1}$ with an average of $6.0 \pm 0.5 \mu \mathrm{g} \mathrm{g}^{-1}$ (RSD 8\%). The studied bivalves show distinct isotope composition ranges: for oysters, $\delta^{65} \mathrm{Cu}_{\mathrm{SRM}}-976$ values are relatively uniform around $+0.38 \pm 0.05 \%$ o $(2 \mathrm{~s}, \mathrm{n}=10)$, while for mussels, the composition display a much wider amplitude $\left(\delta^{65} \mathrm{Cu}_{\max }-\delta^{65} \mathrm{Cu}_{\min }=+0.94 \%\right.$ o $)$ around an average of +1.18 $\pm 0.38 \%$ o $(2 \mathrm{~s}, \mathrm{n}=10)$. The average difference in isotope compositions between mussels and oysters $\left(\Delta^{65} \mathrm{Cu}_{\text {mussel-oyster average }}\right)$ is $+0.81 \%$.

Comparing temporal isotope behavior of hyperaccumulator oysters and regulator mussels 
Copper isotope composition ranges and concentration biomonitoring profiles are remarkably different between oysters and mussels (Fig. 1a,b). In oysters, $\mathrm{Cu}$ concentration time series show an increase between 2011 and 2015, and a decrease from 2015 to 2018 (Fig. 1a). Fluctuations on $\mathrm{Cu}$ concentration in oyster tissues can result from the dynamics of $\mathrm{Cu}$ in estuarine tidal flats and saltmarshes. Thus, changes in $\mathrm{Cu}$ speciation and bioavailability may occur daily due to tidal effects on the sediment geochemical conditions (temperature, salinity, $\mathrm{pH}, \mathrm{Eh}$ ), changes in riverine fluxes of metal or watershed run-off, to particle resuspension episodes (e.g., storms), to influence of primary in the trophic transfer of the metal, etc. ${ }^{49-51}$ Conversely, mussels have a uniform tendency on $\mathrm{Cu}$ concentrations around 6.0-8.0 $\mu \mathrm{g} \mathrm{g}^{-1}$ likely due to their $\mathrm{Cu}$ homeostasis (Fig. 1b). These results are in line with other studies that attest the unfeasibility of M. edulis as a biomonitor of $\mathrm{Cu}$ contamination at low pollution levels. ${ }^{52,53}$

Each bivalve species has their own isotope ranges, with mussels having more positive $\delta^{65} \mathrm{Cu}$ values. Copper isotopes fractionation by different transporter ligands $(\mathrm{O}-, \mathrm{N}-, \mathrm{S}-$, or $\mathrm{C}-$ donors) and redox changes during cellular trafficking have been evoked to explain $\mathrm{Cu}$ isotope variability observed in different organs of plants, mice, dogs, and humans. ${ }^{17,54-60}$ Overall, $\mathrm{Cu}$ (II) displays low coordination, and tends to favor heavy isotopes, in contrast to the reduced form $\mathrm{Cu}(\mathrm{I})$ with high coordination numbers which is enriched in the light isotope. ${ }^{61,62} A b$ initio calculations show that the heavy $\mathrm{Cu}$ isotope is preferentially bound to O-donor ligands, followed by $\mathrm{N}$ - and S- donor ligands. ${ }^{6,55,63}$ By analogy to other organisms, particular isotope range for mussels and oysters can be related to species-specific physiological features on the fractionation of $\mathrm{Cu}$ isotopes at the cellular and tissue levels. Copper is a cofactor in hemocyanin, an oxygen transporter protein that also participates in bivalves' homeostatic and physiological processes $^{64}$. Its oxygenation induces the change from $\mathrm{Cu}$ (I) to $\mathrm{Cu}$ (II) state ${ }^{64}$, and thus may be a factor of isotope fractionation through this metabolic pathway. In parallel, metallothionein proteins that are S-donors have an essential role in the homeostatic control of invertebrates, acting 
as a $\mathrm{Cu}$ stock ready to fulfill enzymatic and metabolic demands, and participating in the intracellular detoxification of excessive $\mathrm{Cu}$ levels ${ }^{34,35,35,61,65,66}$. Mussels differ from oysters with a homeostatic machinery able to excrete excess $\mathrm{Cu}$ as detoxified $\mathrm{Cu}$ forms that are associated with sulfides ${ }^{19,32,35}$. We can hypothesize that the excretion of a detoxified $\mathrm{Cu}$ pool isotopically light may result in a globally heavy isotope composition in these organisms. In contrast, oysters do not possess these cellular excretion mechanisms ${ }^{19,67}$ leaving their global isotope composition unaffected by the internal isotope fractionation mechanisms. While further controlled experiments should be designed to test this hypothesis, the combination of $\mathrm{Cu}$ isotopes with speciation tools (EXAFS, XANES, nanoSIMS, etc.) may be a promising approach to elucidate homeostatic processes in the bivalve organisms.

Temporal $\mathrm{Cu}$ isotope profile patterns of mussel and oysters are similar, but isotope variations differ in magnitude for each species (Fig. 1c). In oyster samples, the isotope composition amplitude of the dataset is small, around $0.17 \%$, but sufficiently to identify wellmarked isotope changes over time (Fig. 1c). Indeed, $\mathrm{Cu}$ isotope data from oysters correlate positively with $\mathrm{Cu}$ concentrations $(\mathrm{r}=0.76, p<0.05)$, suggesting that $\mathrm{Cu}$ isotopes in these organisms respond to the changes in the local $\mathrm{Cu}$ bioavailability (Fig. 2a). Likewise, mussels show a five-fold greater isotope amplitude and a better resolution to discriminate temporal isotope changes (Fig. 1c). No correlation is found between isotope composition and elemental $\mathrm{Cu}$ levels in mussels, likely due to $\mathrm{Cu}$ regulation in homeostatic processes, which result in almost constant concentrations over the sampling period. In order to be able to assess how $\mathrm{Cu}$ isotopes change with the $\mathrm{Cu}$ bioavailability in mussels, we used $\mathrm{Zn}$ concentrations in the same organisms as a proxy of the local $\mathrm{Cu}$ bioavailability. We infer that $\mathrm{Cu}$ and $\mathrm{Zn}$ bioavailabilities at the sample site follow similar temporal trends and that mussels co-bioaccumulate these metals, based on the correlations found in oysters for the ten-year biomonitoring period $(0.99$, $\mathrm{p}<0.05, \mathrm{n}=10$, Fig. S2), and in mussels for the time window covering 1990 to $2018(0.73, p$ 
$<0.05, \mathrm{n}=28$, Fig. S1). The $\delta^{65} \mathrm{Cu}$ values correlate with $\mathrm{Zn}$ concentrations $(\mathrm{r}=0.79, p<0.05)$ displaying sigmoidal shape, which describes an accentuated isotope variation after $\mathrm{Zn}$ concentrations surpass $100 \mu \mathrm{g} \mathrm{g}^{-1}$ followed by a plateau with $\delta$-values around $1.5 \%$ (Fig. 2c). This mussels' sigmoidal isotope pattern clearly differs from the subtle, gradual, and linear isotope variation noted in the oysters, suggesting that distinct bioaccumulation mechanisms may imply in different "sensitivities" of $\mathrm{Cu}$ isotopes in the soft's tissues of each species to vary with the progressive bioaccumulation of $\mathrm{Cu}$. The greater sensitivity or gain for isotope variations observed in mussels may be related to their faster body turnover. Indeed, due to their smaller $\mathrm{Cu}$ body burden associated with high uptake and efflux rates for this metal, ${ }^{68}$ new $\mathrm{Cu}$ inputs in the surrounding environment can rapidly overprint the $\mathrm{Cu}$ isotope recorded in their tissues. In contrast, oysters have a more substantial $\mathrm{Cu}$ body burden accompanied by a conservative bioaccumulation, i.e., without $\mathrm{Cu}$ excretion. Thus, similar mass-balance and flux rate arguments suggest that oyster's shifts in the $\delta^{65} \mathrm{Cu}$ values are smaller than for mussels. ${ }^{19,69}$

The overall shift toward positive $\delta^{65} \mathrm{Cu}$ values with the increase of $\mathrm{Cu}$ bioavailabilities observed in the studied bivalve species seems linked to the input of anthropogenic $\mathrm{Cu}$ sources characterized by heavy isotope signatures, like run-off from increased urbanization materials or new copper-based, anti-fouling paints used to protect submerged structures. Some $\delta^{65} \mathrm{Cu}_{\mathrm{SRM}-976}$ values reported for anthropogenic materials in literature, such as cement $(+0.30$ to $+0.61 \%$ o $){ }^{10}$ road dust $(+0.08$ to $+0.25 \%),{ }^{10}$ vehicular traffic $(+0.46$ to $+0.59 \%),{ }^{10}$ and antifouling paint $(+0.54 \pm 0.03)^{70}$ are characterized by isotope compositions that are heavier than natural average of the Upper Continental Crust $(+0.07 \pm 0.10 \%),{ }^{71,72}$ than the uncontaminated sedimentary materials from estuaries $(-0.04 \pm 0.18 \%)^{73}$, and rivers worldwide $(-1.02$ to $\left.+0.09 \%)\right)^{62}$ Extending the current $\mathrm{Cu}$ isotope bank data for anthropogenic materials and additional investigations on the $\mathrm{Cu}$ isotope fractionation in post-depositional processes will help track $\mathrm{Cu}$ pollutant sources and bioaccumulation routes in bivalves. 
This study demonstrates for the first time that $\mathrm{Cu}$ isotopes in bivalves can detect $\mathrm{Cu}$ bioavailability changes related to diffuse anthropogenic $\mathrm{Cu}$ inputs. For both organisms, isotope signals shift to positive values in agreement with the isotope signatures of anthropogenic $\mathrm{Cu}$ diffuse sources reported in the literature. Nevertheless, we observed different "sensitivities" or "gain" of the isotopic signal in response to the same variation of environmental $\mathrm{Cu}$, and ascribe them to species-specific physiological features. Further studies should test this new biomonitoring tool in specific pollution contexts, and preferentially, accompanied of a cocharacterization of $\mathrm{Cu}$ isotope signatures in environmental matrices and potential anthropogenic end-members, in order to allow an accurate $\mathrm{Cu}$ source apportionment. We also recommend controlled experiments in aquariums or using caged bivalves in the field to elucidate the kinetics of $\mathrm{Cu}$ isotope bioaccumulation in these organisms and to verify the hypothesis of isotope fractionation in mussel's homeostatic processes.

\section{Associated content}

Supporting information (SI) contains the complete bivalve mollusks dataset and statistical data analysis, including a correlation matrix and linear regression plots. This material is available free of charge via the Internet at http://pubs.acs.org.

\section{Acknowledgements}

The authors would like to thank all Ifremer personnel contributing to the ROCCH, especially the LER's, and LERMPL. This work was conducted within the POLLUSOLS project framework which was financed by the regional government of the Pays de la Loire (France). The authors are grateful to anonymous reviewers for their thoughtful and thorough comments in the original manuscript.

\section{References}

(1) Qi, D.; Behrens, H.; Lazarov, M.; Weyer, S. Cu Isotope Fractionation during Reduction Processes in Aqueous Systems: Evidences from Electrochemical Deposition. Contrib Mineral Petrol 2019, 174 (4), 37. DOI 10.1007/s00410-019-1568-4. 
(2) Zhu, X. K.; Guo, Y.; Williams, R. J. P.; O’Nions, R. K.; Matthews, A.; Belshaw, N. S.; Canters, G. W.; de Waal, E. C.; Weser, U.; Burgess, B. K.; Salvato, B. Mass Fractionation Processes of Transition Metal Isotopes. Earth and Planetary Science Letters 2002, 200 (1-2), 47-62. DOI 10.1016/S0012-821X(02)00615-5.

(3) Bigalke, M.; Weyer, S.; Wilcke, W. Copper Isotope Fractionation during Complexation with Insolubilized Humic Acid. Environ. Sci. Technol. 2010, 44 (14), 5496-5502. DOI 10.1021/es1017653.

(4) Balistrieri, L. S.; Borrok, D. M.; Wanty, R. B.; Ridley, W. I. Fractionation of Cu and Zn Isotopes during Adsorption onto Amorphous Fe(III) Oxyhydroxide: Experimental Mixing of Acid Rock Drainage and Ambient River Water. Geochimica et Cosmochimica Acta 2008, 72 (2), 311-328. DOI 10.1016/j.gca.2007.11.013.

(5) Li, D.; Liu, S.-A.; Li, S. Copper Isotope Fractionation during Adsorption onto Kaolinite: Experimental Approach and Applications. Chemical Geology 2015, 396, 74-82. DOI 10.1016/j.chemgeo.2014.12.020.

(6) Moynier, F.; Vance, D.; Fujii, T.; Savage, P. The Isotope Geochemistry of Zinc and Copper. Reviews in Mineralogy and Geochemistry 2017, 82 (1), 543-600. DOI 10.2138/rmg.2017.82.13.

(7) Navarrete, J. U.; Borrok, D. M.; Viveros, M.; Ellzey, J. T. Copper Isotope Fractionation during Surface Adsorption and Intracellular Incorporation by Bacteria. Geochimica et Cosmochimica Acta 2011, 75 (3), 784-799. DOI 10.1016/j.gca.2010.11.011.

(8) Araújo, D. F.; Ponzevera, E.; Briant, N.; Knoery, J.; Bruzac, S.; Sireau, T.; Brach-Papa, C. Copper, Zinc and Lead Isotope Signatures of Sediments from a Mediterranean Coastal Bay Impacted by Naval Activities and Urban Sources. Applied Geochemistry 2019, 111, 104440. DOI 10.1016/j.apgeochem.2019.104440.

(9) Gonzalez, R. O.; Strekopytov, S.; Amato, F.; Querol, X.; Reche, C.; Weiss, D. New Insights from Zinc and Copper Isotopic Compositions into the Sources of Atmospheric Particulate Matter from Two Major European Cities. Environ. Sci. Technol. 2016, 50 (18), 9816-9824. DOI 10.1021/acs.est.6b00863.

(10) Souto-Oliveira, C. E.; Babinski, M.; Araújo, D. F.; Andrade, M. F. Multi-Isotopic Fingerprints (Pb, $\mathrm{Zn}, \mathrm{Cu})$ Applied for Urban Aerosol Source Apportionment and Discrimination. Science of The Total Environment 2018, 626, 1350-1366. DOI 10.1016/j.scitotenv.2018.01.192.

(11) Petit, J. C. J.; Schäfer, J.; Coynel, A.; Blanc, G.; Deycard, V. N.; Derriennic, H.; Lanceleur, L.; Dutruch, L.; Bossy, C.; Mattielli, N. Anthropogenic Sources and Biogeochemical Reactivity of Particulate and Dissolved Cu Isotopes in the Turbidity Gradient of the Garonne River (France). Chemical Geology 2013, 359, 125-135. DOI 10.1016/j.chemgeo.2013.09.019.

(12) Babcsányi, I.; Chabaux, F.; Granet, M.; Meite, F.; Payraudeau, S.; Duplay, J.; Imfeld, G. Copper in Soil Fractions and Runoff in a Vineyard Catchment: Insights from Copper Stable Isotopes. Science of The Total Environment 2016, 557-558, 154-162. DOI 10.1016/j.scitotenv.2016.03.037.

(13) El Azzi, D.; Viers, J.; Guiresse, M.; Probst, A.; Aubert, D.; Caparros, J.; Charles, F.; Guizien, K.; Probst, J. L. Origin and Fate of Copper in a Small Mediterranean Vineyard Catchment: New Insights from Combined Chemical Extraction and $\triangle 65 \mathrm{Cu}$ Isotopic Composition. Science of The Total Environment 2013, 463-464, 91-101. DOI 10.1016/j.scitotenv.2013.05.058.

(14) Viers, J.; Grande, J. A.; Zouiten, C.; Freydier, R.; Masbou, J.; Valente, T.; Torre, M.-L. de la; Destrigneville, C.; Pokrovsky, O. S. Are Cu Isotopes a Useful Tool to Trace Metal Sources and Processes in Acid Mine Drainage (AMD) Context? Chemosphere 2018, 193, 1071-1079. DOI 10.1016/j.chemosphere.2017.11.133.

(15) Babcsányi, I.; Imfeld, G.; Granet, M.; Chabaux, F. Copper Stable Isotopes To Trace Copper Behavior in Wetland Systems. Environ. Sci. Technol. 2014, 48 (10), 5520-5529. DOI 10.1021/es405688v.

(16) Yang, T.; Chen, Y.; Zhou, S.; Li, H. Impacts of Aerosol Copper on Marine Phytoplankton: A Review. Atmosphere 2019, 10 (7), 414. DOI 10.3390/atmos10070414. 
(17) Jouvin, D.; Weiss, D. J.; Mason, T. F. M.; Bravin, M. N.; Louvat, P.; Zhao, F.; Ferec, F.; Hinsinger, P.; Benedetti, M. F. Stable Isotopes of $\mathrm{Cu}$ and $\mathrm{Zn}$ in Higher Plants: Evidence for Cu Reduction at the Root Surface and Two Conceptual Models for Isotopic Fractionation Processes. Environ. Sci. Technol. 2012, 46 (5), 2652-2660. DOI 10.1021/es202587m.

(18) Wang, W.; Fisher, N.; Luoma, S. Kinetic Determinations of Trace Element Bioaccumulation in the Mussel Mytilus Edulis. Mar. Ecol. Prog. Ser. 1996, 140, 91-113. DOI 10.3354/meps140091.

(19) Rainbow, P. S. Trace Metals in the Environment and Living Organisms: The British Isles as a Case Study; Cambridge University Press: Cambridge ; New York, NY, 2018.

(20) Krishnakumar, P. K.; Qurban, M. A.; Sasikumar, G. Biomonitoring of Trace Metals in the Coastal Waters Using Bivalve Molluscs. In Trace Elements - Human Health and Environment; Saleh, $\mathrm{H}$. E.-D. M., El-Adham, E., Eds.; InTech, 2018. DOI 10.5772/intechopen.76938.

(21) Goldberg, E. D. The Mussel Watch - A First Step in Global Marine Monitoring. Marine Pollution Bulletin 1975, 6 (7), 111. DOI 10.1016/0025-326X(75)90271-4.

(22) Schöne, B. R.; Krause, R. A. Retrospective Environmental Biomonitoring - Mussel Watch Expanded. Global and Planetary Change 2016, 144, 228-251. DOI 10.1016/j.gloplacha.2016.08.002.

(23) Farrington, J. W.; Tripp, B. W.; Tanabe, S.; Subramanian, A.; Sericano, J. L.; Wade, T. L.; Knap, A. H. Edward D. Goldberg's Proposal of "the Mussel Watch": Reflections after 40 Years. Marine Pollution Bulletin 2016, 110 (1), 501-510. DOI 10.1016/j.marpolbul.2016.05.074.

(24) Araújo, D.; Machado, W.; Weiss, D.; Mulholland, D. S.; Boaventura, G. R.; Viers, J.; Garnier, J.; Dantas, E. L.; Babinski, M. A Critical Examination of the Possible Application of Zinc Stable Isotope Ratios in Bivalve Mollusks and Suspended Particulate Matter to Trace Zinc Pollution in a Tropical Estuary. Environmental Pollution 2017, 226, 41-47. DOI 10.1016/j.envpol.2017.04.011.

(25) Petit, J. C. J.; Schäfer, J.; Coynel, A.; Blanc, G.; Chiffoleau, J.-F.; Auger, D.; Bossy, C.; Derriennic, H.; Mikolaczyk, M.; Dutruch, L.; Mattielli, N. The Estuarine Geochemical Reactivity of Zn Isotopes and Its Relevance for the Biomonitoring of Anthropogenic $\mathrm{Zn}$ and $\mathrm{Cd}$ Contaminations from Metallurgical Activities: Example of the Gironde Fluvial-Estuarine System, France. Geochimica et Cosmochimica Acta 2015, 170, 108-125. DOI 10.1016/j.gca.2015.08.004.

(26) Shiel, A. E.; Weis, D.; Orians, K. J. Tracing Cadmium, Zinc and Lead Sources in Bivalves from the Coasts of Western Canada and the USA Using Isotopes. Geochimica et Cosmochimica Acta 2012, 76, 175-190. DOI 10.1016/j.gca.2011.10.005.

(27) Shiel, A. E.; Weis, D.; Cossa, D.; Orians, K. J. Determining Provenance of Marine Metal Pollution in French Bivalves Using Cd, Zn and Pb Isotopes. Geochimica et Cosmochimica Acta 2013, 121, 155-167. DOI 10.1016/j.gca.2013.07.005.

(28) Ma, L.; Li, Y.; Wang, W.; Weng, N.; Evans, R. D.; Wang, W.-X. Zn Isotope Fractionation in the Oyster Crassostrea Hongkongensis and Implications for Contaminant Source Tracking. Environ. Sci. Technol. 2019, 53 (11), 6402-6409. DOI 10.1021/acs.est.8b06855.

(29) Weng, N.; Wang, W.-X. Reproductive Responses and Detoxification of Estuarine Oyster Crassostrea Hongkongensis under Metal Stress: A Seasonal Study. Environ. Sci. Technol. 2015, 49 (5), 3119-3127. DOI 10.1021/es505486v.

(30) Sussarellu, R.; Lebreton, M.; Rouxel, J.; Akcha, F.; Rivière, G. Copper Induces Expression and Methylation Changes of Early Development Genes in Crassostrea Gigas Embryos. Aquatic Toxicology 2018, 196, 70-78. DOI 10.1016/j.aquatox.2018.01.001.

(31) Lu, G. Y.; Ke, C. H.; Zhu, A.; Wang, W. X. Oyster-Based National Mapping of Trace Metals Pollution in the Chinese Coastal Waters. Environmental Pollution 2017. DOI 10.1016/j.envpol.2017.02.049.

(32) Amiard-Triquet, C.; Berthet, B.; Metayer, C.; Amiard, J. C. Contribution to the Ecotoxicological Study of Cadmium, Copper and Zinc in the Mussel Mytilus Edulis: II. Experimental Study. Marine Biology 1986, 92 (1), 7-13. DOI 10.1007/BF00392739.

(33) Amiard, J. C.; Amiard-Triquet, C.; Berthet, B.; Metayer, C. Comparative Study of the Patterns of Bioaccumulation of Essential $(\mathrm{Cu}, \mathrm{Zn})$ and Non-Essential $(\mathrm{Cd}, \mathrm{Pb})$ Trace Metals in Various 
Estuarine and Coastal Organisms. Journal of Experimental Marine Biology and Ecology 1987, 106 (1), 73-89. DOI 10.1016/0022-0981(87)90148-1.

(34) Rainbow, P. S. Trace Metal Bioaccumulation: Models, Metabolic Availability and Toxicity. Environment International 2007, 33 (4), 576-582. DOI 10.1016/j.envint.2006.05.007.

(35) Amiard, J.; Amiardtriquet, C.; Barka, S.; Pellerin, J.; Rainbow, P. Metallothioneins in Aquatic Invertebrates: Their Role in Metal Detoxification and Their Use as Biomarkers. Aquatic Toxicology 2006, 76 (2), 160-202. DOI 10.1016/j.aquatox.2005.08.015.

(36) Rosa, M.; Ward, J. E.; Shumway, S. E. Selective Capture and Ingestion of Particles by SuspensionFeeding Bivalve Molluscs: A Review. Journal of Shellfish Research 2018, 37 (4), 727-746. DOI 10.2983/035.037.0405.

(37) Belivermiş, M.; Swarzenski, P. W.; Oberhänsli, F.; Melvin, S. D.; Metian, M. Effects of Variable Deoxygenation on Trace Element Bioaccumulation and Resulting Metabolome Profiles in the Blue Mussel (Mytilus Edulis). Chemosphere 2020, 250, 126314. DOI 10.1016/j.chemosphere.2020.126314.

(38) Griscom, S. B.; Fisher, N. S. Bioavailability of Sediment-Bound Metals to Marine Bivalve Molluscs: An Overview. Estuaries 2004, 27 (5), 826-838. DOI 10.1007/BF02912044.

(39) Baines, S. B.; Fisher, N. S. Modeling the Effect of Temperature on Bioaccumulation of Metals by a Marine Bioindicator Organism, Mytilus Edulis. Environ. Sci. Technol. 2008, 42 (9), 3277-3282. DOI 10.1021/es702336q.

(40) Wright, D. A.; Zamuda, C. D. Copper Accumulation by Two Bivalve Molluscs: Salinity Effect Is Independent of Cupric Ion Activity. Marine Environmental Research 1987, 23 (1), 1-14. DOI 10.1016/0141-1136(87)90013-4.

(41) Pourmozaffar, S.; Tamadoni Jahromi, S.; Rameshi, H.; Sadeghi, A.; Bagheri, T.; Behzadi, S.; Gozari, M.; Zahedi, M. R.; Abrari Lazarjani, S. The Role of Salinity in Physiological Responses of Bivalves. Rev Aquacult 2019, raq.12397. DOI 10.1111/raq.12397.

(42) Hédouin, L.; Metian, M.; Lacoue-Labarthe, T.; Fichez, R.; Teyssié, J.-L.; Bustamante, P.; Warnau, M. Influence of Food on the Assimilation of Selected Metals in Tropical Bivalves from the New Caledonia Lagoon: Qualitative and Quantitative Aspects. Marine Pollution Bulletin 2010, 61 (712), 568-575. DOI 10.1016/j.marpolbul.2010.06.034.

(43) Treguier, C.; Hitier, B. Recherche de l'origine de la contamination microbiologique en rivière de Pénerf. Ifremer March 2013.

(44) Claisse, D. Chemical Contamination of French Coasts. The Results of a Ten Years Mussel Watch. Marine Pollution Bulletin 1989. DOI 10.1016/0025-326X(89)90141-0.

(45) Maréchal, C. N.; Télouk, P.; Albarède, F. Precise Analysis of Copper and Zinc Isotopic Compositions by Plasma-Source Mass Spectrometry. Chemical Geology 1999, 156 (1-4), 251273. DOI 10.1016/S0009-2541(98)00191-0.

(46) Sullivan, K.; Layton-Matthews, D.; Leybourne, M.; Kidder, J.; Mester, Z.; Yang, L. Copper Isotopic Analysis in Geological and Biological Reference Materials by MC-ICP-MS. Geostand Geoanal Res 2020, 44 (2), 349-362. DOI 10.1111/ggr.12315.

(47) Sauzéat, L.; Costas-Rodríguez, M.; Albalat, E.; Mattielli, N.; Vanhaecke, F.; Balter, V. InterComparison of Stable Iron, Copper and Zinc Isotopic Compositions in Six Reference Materials of Biological Origin. Talanta 2021, 221, 121576. DOI 10.1016/j.talanta.2020.121576.

(48) Araújo, D. F.; Boaventura, G. R.; Viers, J.; Mulholland, D. S.; Weiss, D.; Araújo, D.; Lima, B.; Ruiz, I.; Machado, W.; Babinski, M.; Dantas, E.; Araújo, D. F.; Boaventura, G. R.; Viers, J.; Mulholland, D. S.; Weiss, D.; Araújo, D.; Lima, B.; Ruiz, I.; Machado, W.; Babinski, M.; Dantas, E. Ion Exchange Chromatography and Mass Bias Correction for Accurate and Precise Zn Isotope Ratio Measurements in Environmental Reference Materials by MC-ICP-MS. Journal of the Brazilian Chemical Society 2017, 28 (2), 225-235. DOI 10.5935/0103-5053.20160167.

(49) Briant, N.; Savoye, N.; Chouvelon, T.; David, V.; Rodriguez, S.; Charlier, K.; Sonke, J. E.; Chiffoleau, J. F.; Brach-Papa, C.; Knoery, J. Carbon and Nitrogen Elemental and Isotopic Ratios of Filter-Feeding Bivalves along the French Coasts: An Assessment of Specific, Geographic, 
Seasonal and Multi-Decadal Variations. Science of The Total Environment 2018, 613-614, 196207. DOI 10.1016/j.scitotenv.2017.08.281.

(50) de Souza Machado, A. A.; Spencer, K.; Kloas, W.; Toffolon, M.; Zarfl, C. Metal Fate and Effects in Estuaries: A Review and Conceptual Model for Better Understanding of Toxicity. Science of The Total Environment 2016, 541, 268-281. DOI 10.1016/j.scitotenv.2015.09.045.

(51) Du Laing, G.; Rinklebe, J.; Vandecasteele, B.; Meers, E.; Tack, F. M. G. Trace Metal Behaviour in Estuarine and Riverine Floodplain Soils and Sediments: A Review. Science of The Total Environment 2009, 407 (13), 3972-3985. DOI 10.1016/j.scitotenv.2008.07.025.

(52) Przytarska, J. E.; Sokołowski, A.; Wołowicz, M.; Hummel, H.; Jansen, J. Comparison of Trace Metal Bioavailabilities in European Coastal Waters Using Mussels from Mytilus Edulis Complex as Biomonitors. Environ Monit Assess 2010, 166 (1-4), 461-476. DOI 10.1007/s10661-0091015-5.

(53) Julshamn, K.; Kristin Torpe, E.; Børnes, C.; Sæthre, L. J.; Maage, A. Cadmium, Lead, Copper and Zinc in Blue Mussels (Mytilus Edulis) Sampled in the Hardangerfjord, Norway. J. Environ. Monitor. 2001, 3 (5), 539-542. DOI 10.1039/b103047g.

(54) Albarède, F.; Telouk, P.; Lamboux, A.; Jaouen, K.; Balter, V. Isotopic Evidence of Unaccounted for Fe and Cu Erythropoietic Pathways. Metallomics 2011, 3 (9), 926. DOI 10.1039/c1mt00025j.

(55) Balter, V.; Lamboux, A.; Zazzo, A.; Télouk, P.; Leverrier, Y.; Marvel, J.; Moloney, A. P.; Monahan, F. J.; Schmidt, O.; Albarède, F. Contrasting $\mathrm{Cu}, \mathrm{Fe}$, and $\mathrm{Zn}$ Isotopic Patterns in Organs and Body Fluids of Mice and Sheep, with Emphasis on Cellular Fractionation. Metallomics 2013, 5 (11), 1470. DOI 10.1039/c3mt00151b.

(56) Jaouen, K.; Balter, V. Menopause Effect on Blood Fe and Cu Isotope Compositions. American Journal of Physical Anthropology 2014, 153 (2), 280-285. DOI 10.1002/ajpa.22430.

(57) Toubhans, B.; Gourlan, A. T.; Telouk, P.; Lutchman-Singh, K.; Francis, L. W.; Conlan, R. S.; Margarit, L.; Gonzalez, D.; Charlet, L. Cu Isotope Ratios Are Meaningful in Ovarian Cancer Diagnosis. Journal of Trace Elements in Medicine and Biology 2020, 62, 126611. DOI 10.1016/j.jtemb.2020.126611.

(58) Chamel, G.; Gourlan, A. T.; Télouk, P.; Sayag, D.; Milliard, V.; Loiseau, C.; Simon, M.; Buff, S.; Ponce, F. Retrospective Evaluation of Blood Copper Stable Isotopes Ratio 65Cu/63Cu as a Biomarker of Cancer in Dogs. Veterinary and Comparative Oncology 2017, 15 (4), 1323-1332. DOI 10.1111/vco.12273.

(59) Jaouen, K.; Balter, V.; Herrscher, E.; Lamboux, A.; Telouk, P.; Albarède, F. Fe and Cu Stable Isotopes in Archeological Human Bones and Their Relationship to Sex. Am. J. Phys. Anthropol. 2012, 148 (3), 334-340. DOI 10.1002/ajpa.22053.

(60) Costas-Rodríguez, M.; Delanghe, J.; Vanhaecke, F. High-Precision Isotopic Analysis of Essential Mineral Elements in Biomedicine: Natural Isotope Ratio Variations as Potential Diagnostic and/or Prognostic Markers. TrAC Trends in Analytical Chemistry 2016, 76, 182-193. DOI 10.1016/j.trac.2015.10.008.

(61) Cadiou, J.-L.; Pichat, S.; Bondanese, V. P.; Soulard, A.; Fujii, T.; Albarède, F.; Oger, P. Copper Transporters Are Responsible for Copper Isotopic Fractionation in Eukaryotic Cells. Sci Rep 2017, 7 (1), 44533. DOI 10.1038/srep44533.

(62) Wang, Z.; Chen, J.; Zhang, T. Cu Isotopic Composition in Surface Environments and in Biological Systems: A Critical Review. IJERPH 2017, 14 (5), 538. DOI 10.3390/ijerph14050538.

(63) Albarede, F.; Télouk, P.; Balter, V.; Bondanese, V. P.; Albalat, E.; Oger, P.; Bonaventura, P.; Miossec, P.; Fujii, T. Medical Applications of $\mathrm{Cu}, \mathrm{Zn}$, and S Isotope Effects. Metallomics 2016, 8 (10), 1056-1070. DOI 10.1039/C5MT00316D.

(64) Coates, C. J.; Nairn, J. Diverse Immune Functions of Hemocyanins. Developmental \& Comparative Immunology 2014, 45 (1), 43-55. DOI 10.1016/j.dci.2014.01.021.

(65) Wanty, R. B.; Balistrieri, L. S.; Wesner, J. S.; Walters, D. M.; Schmidt, T. S.; Stricker, C. A.; Kraus, J. M.; Wolf, R. E. In Vivo Isotopic Fractionation of Zinc and Biodynamic Modeling Yield Insights into Detoxification Mechanisms in the Mayfly Neocloeon Triangulifer. Science of The Total Environment 2017, 609, 1219-1229. DOI 10.1016/j.scitotenv.2017.07.269. 
(66) Tan, Q.-G.; Wang, Y.; Wang, W.-X. Speciation of $\mathrm{Cu}$ and $\mathrm{Zn}$ in Two Colored Oyster Species Determined by X-Ray Absorption Spectroscopy. Environ. Sci. Technol. 2015, 49 (11), 6919-6925. DOI 10.1021/es506330h.

(67) Wang, W.-X.; Meng, J.; Weng, N. Trace Metals in Oysters: Molecular and Cellular Mechanisms and Ecotoxicological Impacts. Environ. Sci.: Processes Impacts 2018, 20 (6), 892-912. DOI 10.1039/C8EM00069G.

(68) Pan, K.; Wang, W.-X. Biodynamics To Explain the Difference of Copper Body Concentrations in Five Marine Bivalve Species. Environ. Sci. Technol. 2009, 43 (6), 2137-2143. DOI 10.1021/es802888u.

(69) Rainbow, P. S. Trace Metal Concentrations in Aquatic Invertebrates: Why and so What? Environmental Pollution 2002, 120 (3), 497-507. DOI 10.1016/S0269-7491(02)00238-5.

(70) Briant, N. Devenir et biodisponibilité du Cu, Zn et TBT dans un environnement portuaire fortement contaminé : la marina de Port Camargue, Montpellier 2, 2014.

(71) Liu, S.-A.; Huang, J.; Liu, J.; Wörner, G.; Yang, W.; Tang, Y.-J.; Chen, Y.; Tang, L.; Zheng, J.; Li, S. Copper Isotopic Composition of the Silicate Earth. Earth and Planetary Science Letters 2015, 427, 95-103. DOI 10.1016/j.epsl.2015.06.061.

(72) Savage, P. S.; Moynier, F.; Chen, H.; Shofner, G.; Siebert, J.; Badro, J.; Puchtel, I. S. Copper Isotope Evidence for Large-Scale Sulphide Fractionation during Earth's Differentiation. Geochem. Persp. Let. 2015, 53-64. DOI 10.7185/geochemlet.1506.

(73) Araújo, D. F.; Ponzevera, E.; Briant, N.; Knoery, J.; Sireau, T.; Mojtahid, M.; Metzger, E.; BrachPapa, C. Assessment of the Metal Contamination Evolution in the Loire Estuary Using Cu and Zn Stable Isotopes and Geochemical Data in Sediments. Marine Pollution Bulletin 2019, 143, $12-$ 23. DOI 10.1016/j.marpolbul.2019.04.034. 

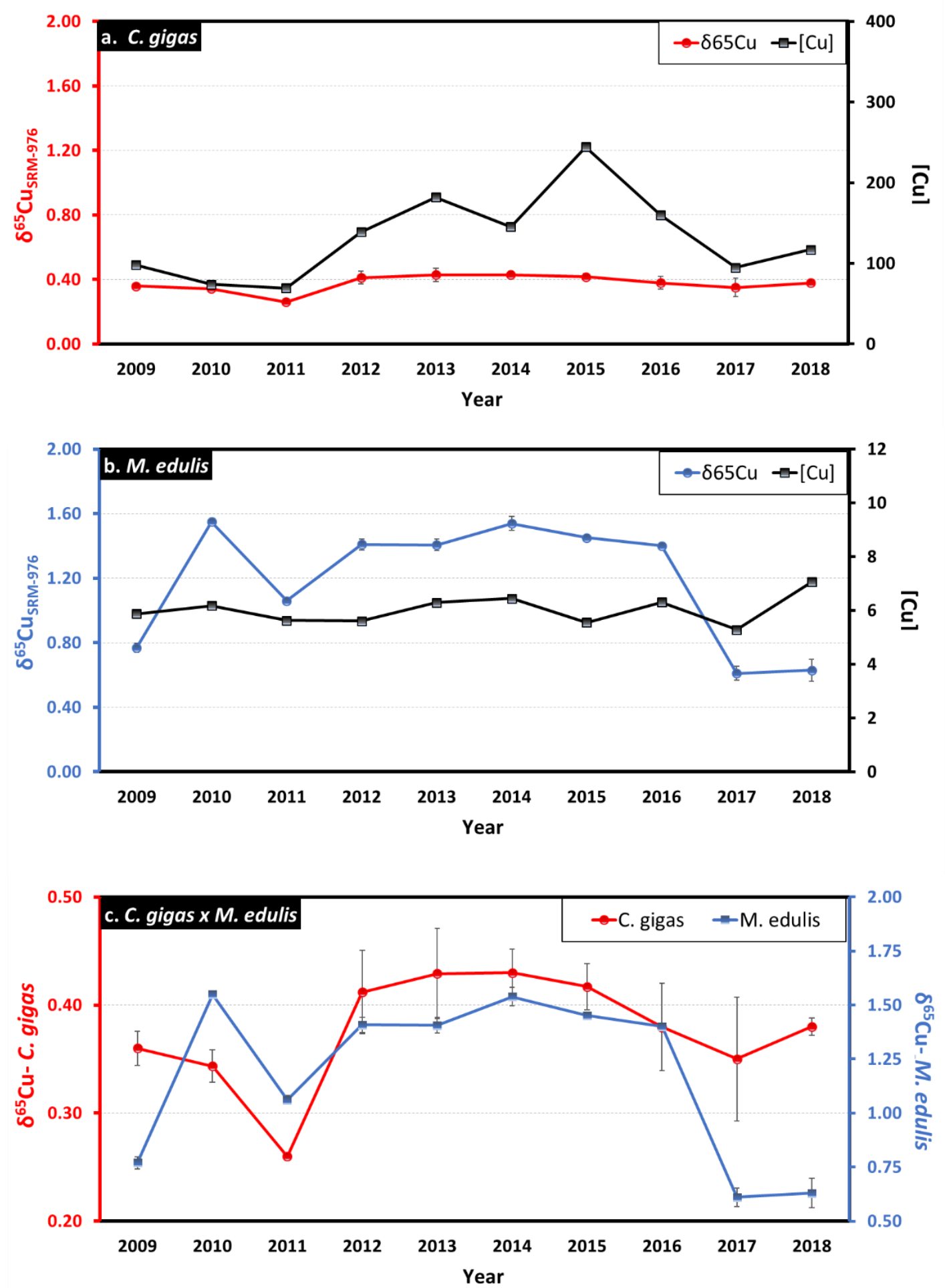

Fig. 1. Elemental $\left(\mu \mathrm{g} \mathrm{g}^{-1}\right)$ and isotope (\%o) temporal profiles of $\mathrm{Cu}$ and $\mathrm{Zn}$ in oysters (Crassostrea gigas) and mussels (Mytilus edulis) along ten years of biomonitoring in the “".Pointe Er Fosse” sampling station. Concentrations are dry-weight based. 

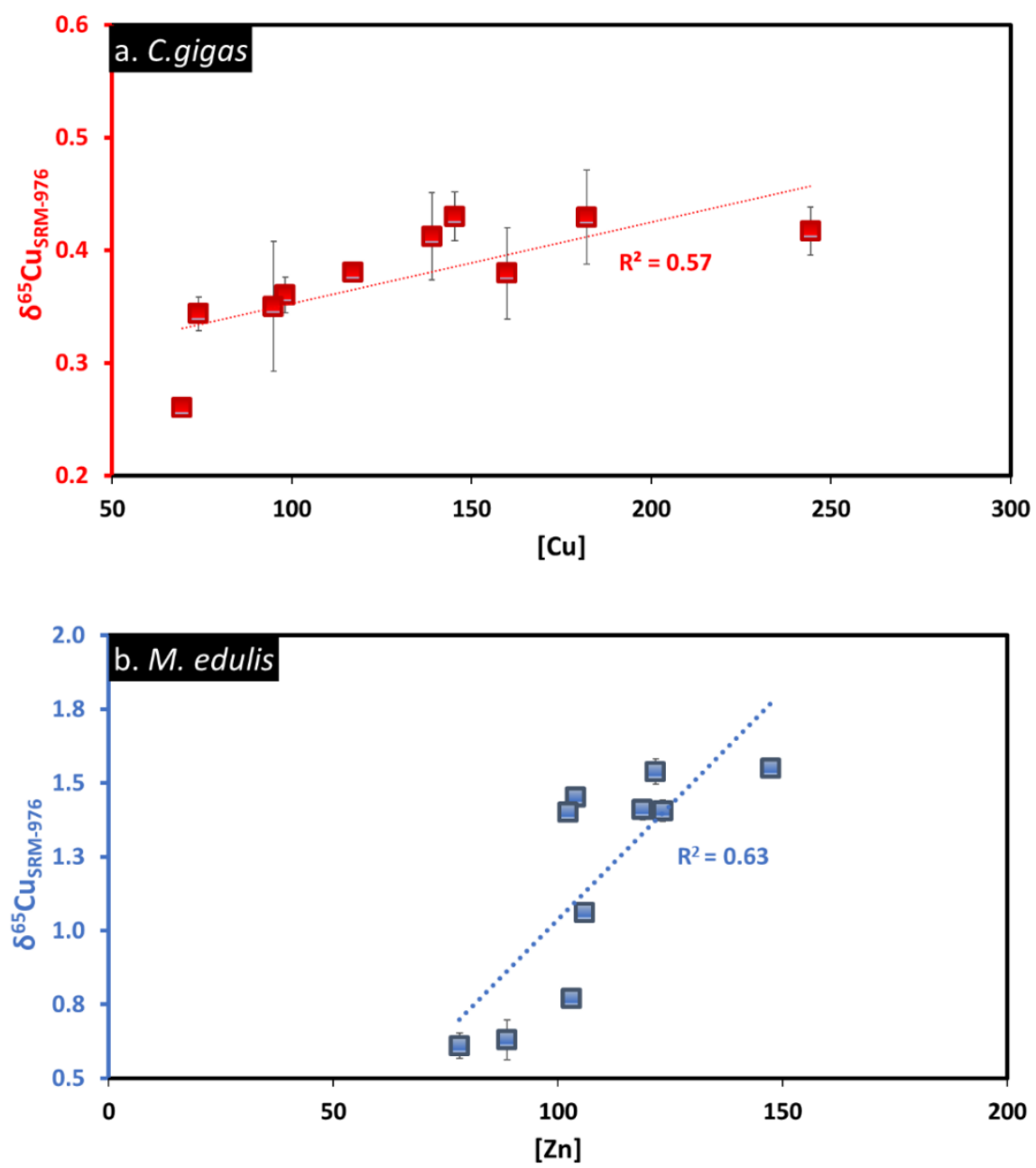

Fig. 2. Dispersion plot of $\mathrm{Cu}$ isotope compositions (\%) and elemental data $\left(\mu \mathrm{g} \mathrm{g}^{-1}\right)$ in oysters (Crassostrea gigas) and mussels (Mytilus edulis) for a ten-year biomonitoring at "Pointe Er Fosse" sampling station. For mussels, $\mathrm{Zn}$ concentrations was used as proxy of $\mathrm{Cu}$ bioavailability in the environment (see text for details). Error bars for mussel data are mostly smaller than the plot square symbols. 
Table 1. Copper isotope compositions of reference materials (RMs).

\begin{tabular}{|cccc|}
\hline & $\begin{array}{c}\delta^{65} \mathrm{Cu}_{\text {NIST-976 }} \\
(\%)\end{array}$ & $2 \mathrm{~s}^{¥}$ & $n^{*}$ \\
ERM-CE278k mussel tissue & 0.16 & 0.09 & 4 \\
SRM1566b oyster tissue & 0.23 & 0.07 & 6 \\
NIST 2976 mussel tissue & 0.14 & 0.01 & 1 \\
DORM-4 fish protein & 0.55 & 0.02 & 1 \\
\hline
\end{tabular}

$¥$ The external reproducibility (2s) is expressed as the two-standard deviations of replicate average values. For RMs prepared in a single replicate, $2 \mathrm{~s}$ refers to the two-standard deviations of two measurements. *Each replicate corresponds to a distinct aliquot processed through digestion, chromatography and measured twice or thrice by MC-ICP-MS. 